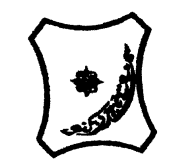

Bayero Journal of Pure and Applied Sciences, 12(2): 122 - 128

Received: November, 2019

Accepted: December, 2019

ISSN $2006-6996$

\title{
ANTIPLASMODIAL AND HAEMATOLOGICAL EFFECTS OF Senna occidentalis LEAF ETHANOLIC EXTRACTS ON SWISS ALBINO MICE INFECTED WITH Plasmodium berghei
}

\author{
$*^{1}$ Babangida, S.M., ${ }^{2}$ Sow, G.J. and ${ }^{2}$ Shehu, D.M. \\ 1. Kano State College of Education and Preliminary Studies, Kano. \\ 2. Department of Zoology, Ahmadu Bello University, Zaria. \\ *Corresponding Author: sakinababangida@gmail.com
}

\section{ABSTRACT}

$A$ research was conducted to investigate the haematological effects of ethanolic leaf extracts of Senna occidentalis on Swiss albino mice infected with $0.2 \mathrm{~m} /$ of Plasmodium berghei infected blood. Fifteen (15) mice weighing between 140-260g were assigned into five study groups of three mice each. The first group is treated with $0.2 \mathrm{~mL}$ of normal saline (drug free control). Group 2, 3, 4 were treated with 100, 200, and 400 mg/kg of the ethanolic leaf extract respectively while group 5 received $10 \mathrm{mg} / \mathrm{kg}$ of chloroquine phosphate. All doses were administered orally. The results obtained were analyzed using Analysis of Variance with Duncan's Multiple Range Test to separate the means. The result of the preliminary phytochemical analysis revealed the presence of alkaloids, saponins, cardiac glycosides, diterpenoids, flavonoids, steroids, tannins, Triterpenoids, carbohydrates and proteins. The level of parasite suppression ranges from $35 \%$ to $75 \%$ and the activity increased with increase in concentration of the extracts (dose dependent). The extracts were found to increase the level of some haematological parameters such as Red Blood Cells, White Blood Cells and Haemoglobin. The effect is concentration dependent, increases with increase in concentration. Thus, the antiplasmodial efficacy of the leaf extract of $S$. occidentalis on P. berghei is confirmed. It is therefore recommended that, $400 \mathrm{mg} / \mathrm{kg}$ leaf ethanolic extracts of $S$. occidentalis could be use in the treatment of malarial fever.

Key Words: Albino mice, Ethanolic Extracts, Concentrations, Plasmodium berghei, Senna occidentalis.

\section{INTRODUCTION}

Malaria remains an important public health concern in countries where transmission occurs regularly, as well as in areas where transmission has been largely controlled or eliminated (WHO, 2001). Malaria is responsible for one to three million deaths and 300 to 500 million infections annually (Krishna et al., 2009; Verma et al., 2011). Children under five and expecting mothers are particularly susceptible to malaria. The disease claims the life of a child every two minutes (WHO, 2018). The African region continues to bear $90 \%$ of malaria cases and $91 \%$ of malaria deaths worldwide and Nigeria, the continent's most populous country, accounted for $27 \%$ of malaria cases and $24 \%$ of malaria deaths globally in 2016 (WHO, 2018). Plasmodium falciparum the most widespread etiological agent for human malaria has become increasingly resistant to standard antimalarials (such as chloroquine and antifolates) and recently to the Artemisinin combination therapies (ACTs) (Sha'a et al., 2011).
Plants are important source of drugs; especially in traditional medicine (Bako et al., 2005). It is a common practice in Nigeria and other parts of the world to use plant in the form of crude extracts, decoction, infusion or tincture to treat common infection and chronic conditions. According to WHO, over $70 \%$ of the world populations rely on medicinal plants for primary health care and there are reports from various researchers on natural substances of plant origin which are biologically active, with desirable antimicrobial and antioxidant properties (Hamid et al., 2010). Medicinal plants have been the focus for the search of new antimalaria drugs in various parts of the world (Schuster, 2001) and the present global situation indicates a recent resurgence in the severity of malaria, due to the resistance of malaria parasites to antimalarial drugs (Peter and Anatoli, 1988). Hence, there is the need to intensify research in the development of new, cheap and effective antimalarial drugs from medicinal plants. 
BAJOPAS Volume 12 Number 2, December, 2019

Senna occidentalis is one of the most widely used herbal plants among people of tropical and sub-tropical regions of the world (Veronique and Gabriel, 2013). It is used for various therapeutic purposes in traditional medicine (Yadav et al., 2010, Silva et al., 2011). It has been used to treat malaria since ancient time and surely if it was not effective, malaria would have devastated Africa (Idowu et al., 2010). It is a most common known practice in Nigeria that, the first line of treatment for $60 \%$ of children with high fever resulting from malaria is the use of herbal medicine at home (WHO, 2001). The rapid spread of resistance Plamodium parasite, makes it necessary to search for more effective herbal antimalarial compounds.

Plasmodium berghei is one of the species of intracellular protozoan parasites from the genus Plasmodium which is responsible for causing malaria. It provides a well established experimental model of malaria infection (Margarida et al., 2006) because of its critical mimicry with the species that infect human (Van der Heyde et al., 2006). The aim of the study is to determine the effect of leaf ethanolic extracts of Senna occidentalis on haematological parameters of Swiss albino mice infected with Plasmodium berghei with the view of testing the efficacy and safety of the extracts in the treatment and control of Plasodium parasites.

\section{MATERIALS AND METHODS Collection and Identification of Samples}

Fresh leaves of Senna occidentalis were obtained from the field at Kura town, Kano state in a clean sterile polythene bag and carried to the herbarium section of the Department of Botany, Ahmadu Bello University Zaria for authentification. Voucher number of 900078 was assigned to the specimen.

\section{Extraction of Plant Ethanolic Extracts}

The extraction methodology followed the protocols of Sasidharan et al. (2011). The collected samples were thoroughly washed and air-dried under shade at room temperature for 2 weeks. The dried leaves were then ground into fine powder with mortar and pestle, and were stored in dry containers until needed. The ethanolic extracts of $S$. occidentalis leaves were prepared by soaking $100 \mathrm{~g}$ of each powder in $150 \mathrm{ml}$ of $95 \%$ ethanol and shaken in orbital shaker at $120 \mathrm{rpm}$. The preparations were left to stand for another 24 hours and then filtered through a gauze and then Whatman No 1 filter paper. The filtrates were concentrated to dryness at $40^{\circ} \mathrm{C}$ under reduced pressure on a rotary evaporator and were stored in a refrigerator at $-4^{\circ} \mathrm{C}$ until the need arise.
Different concentrations of 100, 200 and $400 \mathrm{mg} / \mathrm{kg}$ of the ethanolic extracts were prepared from the leaves of $S$. occidentalis.

\section{Phytochemical Analysis}

The phytochemical screening of the ethanolic extract of $S$. occidentalis was carried out according to the methods described by Sofowara (1993), Mukherjee (2006) and Adegoke et al. (2010) to determine the presence of active constituents in the plant leaves. Ethanolic extract of $S$. occidentalis was subjected to qualitative test for the presence of bioactive components that include Molisch's test for detection of Carbohydrates, Meyer's test for detection of Alkaloids, Wagner's test for detection of Alkaloids, Lead subacetate test for detection of Tannins, Keller- Killiani's test for detection of Cardiac Glycosides, Frothing/Foaming test for detection of Saponins, Libermann-Burchard's test for detection of Steroids and Triterpenoids, Copper Acetate's test for detection of Diterpenoids, Alkaline test for the detection of Flavonoids, Xanthoproteic test for the detection of Protein and Borntrager's test for the detection of Anthraquinones.

\section{Experimental Animals}

Ethical clearance was obtained from Ahmadu Bello University Committee on Animal Use and Care (ABUCAUC). The protocol employed met the guidelines of the Good Laboratory Practice (GLP) regulations of World Health Organization. Apparently healthy white Swiss albino mice of both sexes weighing between 140 and $260 \mathrm{~g}$ were used for the work and were obtained from the Faculty of Veterinary Medicine, Ahmadu Bello University, Zaria. The mice were housed in metal cages and kept in a well ventilated room with 12 hours dark/light cycle. They were fed with standard feed pellets and tap water ad libitum. The animals were acclimatized for 2 weeks before proceeding with the experiment.

\section{Inoculation}

$P$. berghei was obtained from the Department of Parasitology and Entomology, Faculty of Veterinary Medicine, Ahmadu Bello University, Zaria. Parasites were harvested from the blood of a donor rat at peak parasitemia $\left(10^{9}\right.$ parasites $/ \mathrm{ml}$ ) and was diluted with normal saline and then used for infection of experimental animals. The inoculums consisted of $P$. berghei berghei parasitized erythrocytes. This was prepared by determining both the percentage parasitemia and the erythrocytes count of the donor mouse and diluting the blood with normal saline in proportions indicated by both determinations as described by Akuodor et al. (2010). 
BAJOPAS Volume 12 Number 2, December, 2019

Each mouse was inoculated on day 0 , intraperitoneally with $0.2 \mathrm{ml}$ of infected blood containing approximately $1 \times 10^{7} \quad P$. berghei parasitized red blood cells. In addition, the newly inoculated animals were monitored daily to determine their degree of infestation with the parasite.

A 4-day suppressive test was conducted according to the method described by Mbah et al. (2012). After four hours of inoculation, the infected mice were randomly divided into 5 groups of 3 mice per cage and were treated for four consecutive days. Group 1 received $0.2 \mathrm{~mL}$ of normal saline (drug free control). Group 2, 3, 4 received 100,200 and $400 \mathrm{mg} / \mathrm{kg}$ of the ethanol leaf extract respectively while group 5 received $10 \mathrm{mg} / \mathrm{kg}$ of chloroquine phosphate. All

Percentage of Infected RBCs $=$ Number of infected RBCs $\quad \times 100$

Total Number of RBCs Counted

Average chemo suppression was calculated as

$\%$ Suppression $=$ Average parasitemia in Control-Average parasitemia in Treated $\times 100$

Average parasitemia in Control

\section{Acute Toxicity Test}

The safety of the extract to the mice was determined by estimating the lethal concentration $\left(\mathrm{LC}_{50}\right)$ of the ethanolic leaf extract of $S$. occidentalis using the method as described by Lorke (1983) with modification. Mice of both sexes were starved for 8 hours prior to the toxicity test. The study was carried out. The mice were administered 100, 200 and $400 \mathrm{mg} / \mathrm{kg}$ of the leaf extract. The acute toxicity $\mathrm{LC}_{50}$ was calculated as geometric mean of the concentration that resulted in $100 \%$ lethality and that which caused no lethality at all. Toxicity signs such as death, changes in physical appearance or behavioral changes were observed for over a period 72 hours after administration of the plant extract.

Packed cell volume (PCV) was measured to predict the effectiveness of the test extract in preventing haemolysis resulting from increased doses were administered orally using oral cannula according to their weight. On the fifth day, thin film of blood was collected from the tail of each mouse and thick films fixed with methanol, stained with 4\% Giemsa at pH 7.2 for 30 min were prepared. Parasitemia was determined by counting the parasitised red blood cells out of 1000 red blood cell in 10 random macroscopic fields. Slides were viewed using light microscopy with oil immersion (X1000 magnification). The percentage of infected RBCs was determined by enumerating the number of infected RBCs in relation to the number of uninfected RBCs as described by Akuodor et al. (2010). A minimum of 500 RBCs total was counted.

parasitaemia. Heparinized capillary tubes were used for collection of blood from tail of each mouse. Blood sample collected was suspended in EDTA to prevent blood coagulation. The capillary tubes were filled with blood up to three-third of their volume and sealed at the dry end with sealing clay. The tubes were then placed in a micro-haematocrit centrifuge (Gelma Awhksley, England) with the sealed end outwards and centrifuged for $5 \mathrm{~min}$ at $12,000 \mathrm{rpm}$. The tubes were then taken out of the centrifuge and PCV was determined using a standard micro-haematocrit reader using the protocols of Dacies and Lewis (1975). Haemaglobin level was determined by the method of Crosby et al. (1954) as modified by Pla and Fritz (1971). Estimation of white and red blood cell counts were computed using the method described by Dacies and Lewis (1975).

The formula for computing the PCV follows the following relationship:

$\mathrm{PCV}=$ Volume of Erythrocytes in a Given Volume of Blood

Total Blood Volume

\section{Statistical Analyses}

The data obtained from the suppression test and effects of the extracts on haematological parameters were analyzed using one-way Analysis of Variance (ANOVA) with Duncan's Multiple Range Test (DMRT) for separating the means that were significant.

\section{RESULTS}

The result for the phytochemical screening of the leaf extracts of $S$. occidentalis is presented in Table 1 . The result revealed the presence of ten active constituents in the form of alkaloids, carbohydrates, cardiac glycosides, diterpenoids, flavonoids, proteins, saponins, steroids, tannins and triterpenoids. 
BAJOPAS Volume 12 Number 2, December, 2019

Table 1: Phytochemical Constituents of the Leaves of S. occidentalis

\begin{tabular}{cccc}
\hline S/N & Phytochemical Compound & Test & Result \\
\hline 1 & Alkaloids & Wagner's test & + \\
2 & Anthraquinones & Bornfrager's & + \\
3 & Carbohydrate & Molisch & + \\
4 & Cardiac glycosides & Keller-Killani & + \\
5 & Diterpenoids & Copper acetate & + \\
6 & Flavonoids & Alkaline reagent test & + \\
7 & Protein & Xanthoproteic & + \\
8 & Saponins & Frothing test & + \\
9 & Steroids & LibermannBuchard's test & + \\
10 & Tannins & Lead subacetate test & + \\
\hline 11 & Triterpenoids & LibermannBuchard's test & \\
\hline
\end{tabular}

Key: $(+)=$ Present $\quad(-)=$ Absent

The result for acute toxicity test revealed no mortality observed in mice after oral administration of the ethanolic leaf extracts and the $\mathrm{LC}_{50}$ value of $1000 \mathrm{mg} / \mathrm{kg}$ was estimated which signifies that the oral $\mathrm{LC}_{50}$ was greater than $1000 \mathrm{mg} / \mathrm{kg}$. There were no observed clinical signs of toxicity in the treated mice during a 4-day observation period except mild drowsiness and mild weakness in the treated mice.

However, the result for the in vivo assays for four- day suppressive effect is presented in Table 2. The result for the percentage suppression analysis of the leaf ethanolic extracts of $S$. occidentalis revealed significant decrease $(P \leq 0.05)$ in parasitaemia at all dose levels as compared to the negative control group. The group that received $400 \mathrm{mg} / \mathrm{kg}$ of the extract exhibited maximal suppression (75.00\%) of parasitaemia than the other groups. All doses of the extract significantly enhanced the survival time of the mice in a dose dependent manner as compared to the negative control group (Table 2). The percentage suppression increases with increase in concentration of the extracts.

Table 2: Effect of Leaf Ethanolic Extract of S. occidentalis on P. berghei infected mice on suppressive test

\begin{tabular}{cccc}
\hline $\mathbf{S} / \mathbf{N}$ & Dose $(\mathbf{m g} / \mathbf{k g})$ & $\begin{array}{c}\text { Parasitemia Level/ } \mathbf{\mu l} \text { of } \\
\text { Blood }\end{array}$ & \% Suppression \\
\hline 1 & Control I & $4.20 \pm 0.21^{\mathrm{a}}$ & - \\
2 & Control II & $4.10 \pm 0.40^{\mathrm{a}}$ & 2.00 \\
3 & 100 & $2.70 \pm 0.1^{\mathrm{b}}$ & 35.00 \\
4 & 200 & $1.83 \pm 0.55^{\mathrm{c}}$ & 56.00 \\
5 & 400 & $1.03 \pm 0.03^{\mathrm{d}}$ & 75.00 \\
\hline
\end{tabular}

Key: Control I: $0.2 \mathrm{~mL}$ Normal Saline, Control II: $10 \mathrm{mg} / \mathrm{kg}$ of Chloroquine

More so, the result for the effect of different concentrations of the extracts on haematological characteristics of the experimental animals is shown in Table 3. The result on the Packed Cell Volume of the Swiss albino mice infected with Plasmodium berghei and treated with different concentrations of the extracts showed significant increase $(P \leq 0.05)$ in PCV level with increase in the concentrations of the extracts. Similar results were found in the haemoglobin and Red Blood Cells levels. The levels of PCV, $\mathrm{Hb}$ and RBC decreased among the positive and negative controls. However, $100 \mathrm{mg} / \mathrm{kg}$ of the extracts showed increased in the levels of White blood cells while $400 \mathrm{mg} / \mathrm{kg}$ and the negative control inducing the least.

Table 3: Effect of leaf extract on some haematological parameters

\begin{tabular}{cccccc}
\hline \multirow{2}{*}{ Parameters } & $\begin{array}{c}\mathbf{0 . 2 m l} \\
\text { Normal saline }\end{array}$ & $\begin{array}{c}\mathbf{1 0} \mathbf{~ m g / k g} \\
\text { Chloroquine }\end{array}$ & $\mathbf{1 0 0} \mathbf{m g} / \mathbf{k g}$ & $\mathbf{2 0 0} \mathbf{m g} / \mathbf{k g}$ & $\mathbf{4 0 0} \mathbf{m g} / \mathbf{k g}$ \\
\hline PCV & $31.30 \pm 0.88^{\mathrm{d}}$ & $42.00 \pm 7.02^{\mathrm{c}}$ & $42.00 \pm 6.56^{\mathrm{c}}$ & $45.67 \pm 1.20^{\mathrm{b}}$ & $56.67 \pm 2.40^{\mathrm{a}}$ \\
Hb & $10.50 \pm 0.39^{\mathrm{d}}$ & $13.97 \pm 2.33^{\mathrm{c}}$ & $13.63 \pm 1.86^{\mathrm{c}}$ & $15.20 \pm 0.42^{\mathrm{b}}$ & $17.87 \pm 1.94^{\mathrm{a}}$ \\
RBC & $5.70 \pm 0.38^{\mathrm{d}}$ & $7.17 \pm 1.17^{\mathrm{C}}$ & $7.01 \pm 0.92^{\mathrm{c}}$ & $7.83 \pm 0.50^{\mathrm{b}}$ & $9.33 \pm 0.48^{\mathrm{a}}$ \\
WBC & $8.97 \pm 1.79^{\mathrm{c}}$ & $7.67 \pm 1.73^{\mathrm{d}}$ & $13.97 \pm 2.03^{\mathrm{b}}$ & $16.93 \pm 1.22^{\mathrm{a}}$ & $7.87 \pm 1.27^{\mathrm{d}}$ \\
\hline
\end{tabular}


BAJOPAS Volume 12 Number 2, December, 2019 DISCUSSION

The presence of vast array of phytochemicals in the leaves of $S$. occidentalis signifies the relative importance of this plant in the treatment of $P$. berghei infections. This finding is in agreement with that of Saidu et al. (2011) who reported that, the efficacy of $S$. occidentalis leaf extracts in the treatment of Salmonella typhi infections depends on the phytochemical constituents of the extracts. The fact that, malarial parasites depend on blood and blood system, analysis of the effects of such parasites and efficacy of the extracts on blood parameters is critical in understanding the mechanism of infection and control. It is a known fact that malaria infection leads to anaemia as reported by Balogun et al. (2009). More so, the growing parasite consumes and degrades the intracellular proteins which are mainly hemoglobin as stressed by Gavigan et al. (2001). This may account for further reduction in Hemoglobin level. These reductions were considerably reversed in the infected mice treated with the extracts. This suggests that the extract may enhance the production of red blood cells. This subsequently causes an increase in $\mathrm{PCV}$ and $\mathrm{Hb}$ levels observed in extract treated mice. However, the decrease in the RBC, WBC and $\mathrm{Hb}$ level exposes the animal to several potential health hazards such as anaemia, low immune system and suffocation. Decrease in WBC level in infected mice leaves the mice at great risk of having infections. The observed increase in WBC in the infected mice group treated with $100 \mathrm{mg} / \mathrm{kg}$ of the leaf extract may probably be as a result of stimulation of the immune system of the mice to fight malaria parasites as reported by Yakubu et al. (2007). The ethanolic extract has the ability of boosting the immune-response of the infected mice. Thus, the plasmodium infections affect the intestine at the immunological level when the immune system is low as reported by Wang et al. (2013).

In acute toxicity test, no adverse effect or mortality was observed in the mice up to during the $72 \mathrm{~h}$ observation. This finding is in conformity with the previous report contained in the guideline set by Organization for Economic Co-operation and Development, OECD (2001) and Akhila et al. (2007) that these plants are not toxic and safe for use. This finding is also in conformity with the earlier work of Ayoka et al. (2005) and Uchendu and Isek (2008) who individually reported similar findings using Spondias mombin extracts. Similar finding was also reported by Sini et al. (2010) using Cassia occidentalis extracts. The $S$. occidentalis extracts show significant effects on the the haematological parameters of infected mice. The extracts displayed erythropoesis as indicated by significant increase in the PCV (42.00-56.67\%) compared to the controls (31.30-42.00\%). Erythropoesis is an increase in the level of red blood cells than normal compared to the whole blood. This finding is in conformity with the previous work of Taylor (2006) who reported similar finding using Spondias mombin extracts and that of Yadav et al. (2009) who reported significant role played by Cassia occidentalis extracts in increasing the levels of haematological parameters. Similarly, Hamenoo (2010) reported increased in the levels of haematological parameters due to $S$. mombin extracts administration in rodents. Similarly, the haematological parameters of all the test animals treated with the leaf extracts of $C$. occidentalis increased significantly. This finding corresponds to that of Nuhu and Aliyu (2008) who reported significant increased in the level of haematological parameters of $C$. occidentalis extracts treated rats. More so, Emeka and Funmilayo (2011) reported similar finding among alloxan-induced diabetic rats treated with the extracts of $S$. mombin and Parinari polyandra.

More so, the acute toxicity assessment of the extracts on to the test animals shows no gross physical and behavioral changes such as anorexia, diarrhea, depression, abnormal secretion and hair erection for $24 \mathrm{~h}$. All the mice survived the 2-week observation period. The direct toxic effects of the crude extract on blood parameter (PCV) in healthy mice were evaluated by administering higher doses of the extract.

\section{CONCLUSION}

It was concluded that, the leaf ethanolic extracts of Senna occidentalis significantly reduce paracetaemia due to $P$. berghei infection and did not show any toxicity effect. Thus, the extracts within the range of $100-400 \mathrm{mg} / \mathrm{kg}$ is safe for consumption and effective against malaria. It was therefore recommended that, $400 \mathrm{mg} / \mathrm{kg}$ leaf ethanolic extracts of Senna occidentalis is the most effective dose in the treatment of malarial infection caused by $P$. berghei..

\section{Acknowledgements}

The authors wish to acknowledge the support of the Department of Biology and Faculty of Veterinary Medicine, Ahmadu Bello University, Zaria. 
BAJOPAS Volume 12 Number 2, December, 2019

\section{REFERENCES}

Adegoke, A.A., Iberi, P.A., Akinpelu, D.A., Aiyegoro, O.A., and Mboto, C.I. (2010). Studies onphytochemical screening and antimicrobial potentials of Phyllanthus amarus against multiple antibiotic resistant bacteria. International Journal of Applied Research in Natural Products, 3(3):6-12.

Akhila, J.S., Deepa, S. and Alwar, M.C. (2007). Acute toxicity studies and determination of median lethal dose. Current Science, 7(93): 917-920.

Akuodor, G.C., Idris-Usman, M., Ugwu, T.C., Akpan, J.L., Ghasi, S.I., and Osunkwo, U.A. (2010). In vivo schizontal activity of ethanolic leaf extract of Gongronema latifolium on Plasmodium berghei berghei in mice. Afr. J. Biothech., 10;9(5): 2316-2321.

Ayoka, A.O., Akomolafe, R.O., Iwalewa, E.O., and Ukponmwan, O.E. (2005). Studies on the anxiolytic effect of Spondias mombin L (Anacardiaceae) extracts. African Journal of Traditional, Complementary and Alternative Medicine, 2(2): 153-165.

Bako, S.P., Bakfur, M.J., John, I., and Bala, E.I. (2005). Ethnomedicinal and phytochemical profile of some savanna plant species in Nigeria. International Journal of Botany, 1(2): 147-150.

Balogun, E.A., Adebayo, J.O., Zailani, A.H., Kolawole, O.M., and Ademowo, O.G. (2009). Activity of ethanolic extract of Clerodendrum violaceum leaves against Plasmodium berghei. Agric. Biol. J.N. Am., 1(3), 307-312

Crosby, W.H., Munn, J.I., and Furth FW. (1954). Standardizing methods for clinical hemoglobinometry. US Armed Forces Med. J., (5):693-703.

Dacies, J.V., and Lewis, S.M. (1975). Practical hematology. 5th (ed) Edinburge: Church Hill. Livingstone. 541-675.

Emeka, E.J.I., and Funmilayo, D.O. (2011). Hypoglycaemic effect, biochemical and histological changes of Spondias mombin Linn. and Parinari polyandra Benth seeds ethanolic extracts in alloxan-induced diabetic rats. Journal of Pharmacology and Toxicology, 6(2): 101-112.

Gavigan, C.S., Dalton, J.P., and Bell, A. (2001). The role of aminopeptidases in haemoglobin degradation in Plasmodium falciparum infected erythrocytes. Mol. Biochem. Parasitol., 117(1), 37-48.
Hamenoo, N.A. (2010). Hepatoprotective and toxicological assessment of Spondias mombin L. (Aanacardiaceae) in rodents. Department Pharmacology, Faculty of Pharmacy and Pharmaceutical Sciences, Kwaame Nkrumah University of Science and Technology, Kumasi. 1-88 pp.

Hamid, A.A., Aiyelaagbe, O.O., Usman, L.A., Ameen, O.M., and Lawal, A. (2010). Antioxidants: Its medicinal and pharmacological applications. African Journal of Pure and Applied Chemistry, 4(8): 142-151.

Idowu, O.A., Soniran, O.T., Ajana, O., and Aworinde, D.O. (2010). Ethnobotanical Survey ofantimalarial plants used in Ogun State, Southwest Nigeria. African Journal of Pharmacy and Pharmacology, 2010;4:55-60.

Krishna, A.P., Chandrika, S.K., Kumar, S., Acharya, M., and Patil, S.L. (2009). Variation in common lipid parameters in malaria infected patients. Indian $J$. Physiol. Pharmacol., 53: 271-74.

Margarida, C., Silva, P., Maria, F., and Maria, M.M. (2006). Infection by and protective immune responses against Plasmodium berghei ANKA are not affected in macrophage scavenger receptors a deficient mice. BMC Microbiol., 6: 1-5.

Mbah, C.C., Akuodor, G.C., Anyalewachi, N.A., Iwuanyanwu, T.C., and Osunkwo, U.A, (2012). In vivo antiplasmodial activities of aqueous extract of Bridelia ferrogenea stem bark against Plasmodium berghei berghei in mice. Pharmaceutical Biology, 50 (2);188-194.

Mukherjee, P.R. (2006). Quality control of herbal drugs an approach to Evaluation of Botanicals.13 ${ }^{\text {th }}$ Edition. New Delhi Business Horizones Publisher. 416-459 pp.

Nuhu, A.A., and Aliyu, R. (2008). Effects of Cassia occidentalis aqueous leaf extract on

biochemical markers of tissue damage in rats. Tropical Journal of Pharmaceutical Research, 7(4):1137-1142.

Organization for Economic Co-operation and Development/OECD (2001). Acute oral toxicity fixed dose procedure. OECD Guideline for Testing of Chemicals 420: 1-14.

Peter, I.T., and Anatoli, V.K. (1988). The Current Global Malaria Situation: Malaria Parasite Biology, Pathogenesis, and Protection, ASM Press, Washington, DC, USA, 38-43 Prospects and challenges: spatula DD 1(3): 167-174. 
BAJOPAS Volume 12 Number 2, December, 2019

Pla, G.W., and Fritz, J.C. (1971). Collaborative test in chicks and rats for measuring availability of Iron. Journal of Association of Analytical Chemist., 54(1), 13-17.

Saidu, A.N., Aina, E.O., Mann, A., and Leje, U.I. (2011). The effect of aqueous extract of Senna occidentalis leaves on rats infected with Salmonella typhi. Australian Journal of Basic and Applied Sciences, 5(12): 1863-1867.

Sasidharan, S., Chen, Y., Saravanan, D., Sundram, K., and Yoga Latha, L. (2011). Extraction, isolation and characterization of bioactive compounds from plants' extracts. Afr J Tradit Complement Altern Med. 8:1-10.

Schuster, B.G. (2001). Demonstrating the validity of natural products as antiinfective drugs. Journal of Alternative and Complementary Medicine, 7(1): 7382.

Sha'a, K.K., Oguche, S., Watila, I.M. and Ikpa, T.F. (2011). In vitro antimalarial activity of the extracts of Vernonia amygdalina commonly used in traditional medicine in Nigeria. Science World Journal, 6(2): 5-9.

Silva, M.G.B., Aragão, T.P., Vasconcelos, C.F.B., Ferreira, P.A., Andrade, B.A., Costa, I.M.A., Costa Silva, J.H., Wanderley, A.G., and Lafayette, S.S.L. (2011). Acute and sub-acute toxicity of Cassia occidentalis L. stem and leaf in Wistar rats. Journal of Ethnopharmacology, 136: 341-346.

Sini, K.R., Karpakavalli, M., and Sangeetha, P.T. (2010). Analgesic and antipyretic activity of Cassia occidentalis linn. World Applied Sciences Journal, 11(10): 1216-1219.

Sofowara, A. (1993). Medicinal plants and traditional medicine in Africa. Ibadan, Nigeria. Spectrum Book LTD. 289 pp.

Taylor, L.N.D. (2006). Database Entry for UbosSpondias mombin. 1-5 pp.

Uchendu, C.N., and Isek, T. (2008). Antifertility activity of aqueous ethanolic leaf extracts of Spondias mombin (Anacardiaceae) in rats. African Health Sciences, 8: 163-167.
Van der Heyde, H.C., Nolan, J., Combes, V., Gramaglia, I., and Grau, G.E. (2006). A unified hypothesis for the genesis of cerebral malaria: Sequestration, inflammation and hemostasis leading to microcirculatory disfunction. Trends Parasitol., 22: $503-08$.

Verma, G., Dua, V.K., Agarwai, D.D., and Atul, P.K. (2011). Anti-malarial activity of Holarrhena antidysenterica and Viola canescens, plants traditionally used against malaria in the Garhwal region of north-west Himalaya. Malar J. 10: 20.

Veronique, J.E., and Gabriel, N.M. (2013). Subchronic toxicity of the beverage made from Cassia occidentalis seeds in mice. International Journal of Nutrition and Food Sciences, 2(5):237-242.

Wang, M.L., Cao, Y.M., Luo, E.J., Zhang, Y., and Guo, Y.Y.J. (2013). Pre-existing Schistosoma japonicum infection alters the immune response to Plasmodium berghei infection in $\mathrm{C} 57 \mathrm{BL} / 6$ mice. $J$. Malar. Pub.Med Central, 12: 322.

WHO (2001). Drug resistance in malaria, Switzerland. World Health Organization, 1-27 pp.

WHO (2018) World Malaria Day Ready to beat malaria. Switzerland. World Health Organization, 1-3 pp.

Yadav, J.P., Arya, V., Yadav, S., Panghal, M., Kumar, S., and Dhankhar, S. (2009). Cassia occidentalis. A review on its ethnobotany, phytochemical and pharmacological process. Fitoterapia 10: 1016.

Yadav, J.P., Vedpriya, A., Sanjay, Y., Manju, P., Sandeep, K., and Seema, D. (2010). Cassia occidentalis L.: A review on its ethnobotany, phytochemical and pharmacological profile. Fitoterapia, 81(4):223-230.

Yakubu, M.T., Akanji, M.A., and Oladiji, A.T. (2007). Hematological evaluation in male albino rats following chronic administration of aqueous extract of Fadogia agrestis stem. Phcog. Mag., 3(9): 34-38. 